\title{
Velocity of radio-wave propagation in ice at Vostok station, Antarctica
}

\author{
Sergey V. POPOV, ${ }^{1}$ Alexander N. Sheremet’YeV, ${ }^{1}$ Valery N. MasoloV, ${ }^{1}$ Valery V. LUKin, ${ }^{2}$ \\ Anatoliy V. MIRONOV, ${ }^{1}$ VAdim S. LUCHININOV ${ }^{3}$ \\ ${ }^{1}$ Polar Marine Geological Research Expedition (PMGRE), 24 Pobeda Street, Lomonosov, 189510 St Petersburg, Russia \\ E-mail:spopov@polarex.spb.ru \\ ${ }^{2}$ Russian Antarctic Expedition (RAE), 38 Bering Street, 199397 St Petersburg, Russia \\ ${ }^{3}$ GNPP "Sevmorgeo", 36 Rozenshteyna Street, 198095 St Petersburg, Russia
}

\begin{abstract}
During the austral summer field season of the Russian Antarctic Expedition in 1999/2000, wide-angle reflections experiments were performed in the vicinity of the Russian station Vostok. A $60 \mathrm{MHz}$ ice radar system with 12-bit digital recording was used. The measurements were taken along two perpendicular lines directed south-north and east-west with a distance of $200 \mathrm{~m}$ between marks. We used a one-layer model (without snow-firn zone influence) for the calculations. We calculate that the average velocity of radio-wave propagation in the ice sheet is $168.4 \pm 0.5 \mathrm{~m} \mu \mathrm{s}^{-1}$. The same velocity was derived from hyperbolic diffractions from internal discontinuities. The results allow more accurate depth interpretation of radio-echo soundings.
\end{abstract}

\section{INTRODUCTION}

Throughout the last several years the Polar Marine Geological Research Expedition (PMGRE) has carried out radio-echo sounding (RES) investigations of lake Vostok beneath the Antarctic ice sheet (Masolov and others, 1999; Lukin and others, 2000; Popov and others, 2000). To increase the accuracy of the RES data, PMGRE measured the radio-wave propagation velocity in ice in the vicinity of the Russian station Vostok during austral summer field season 1999/2000. The measurements were carried out using the wide-angle reflection method (Popov and others, 2001). Similar measurements previously performed in Antarctica (Robin and others, 1969; Clough and Bentley, 1970; Trepov, 1970; Jiracek and Bentley, 1971; Van Autenboer, 1972; Drewry, 1975; Bogorodsky and others, 1985; Sheremetiev, 1989) have given velocities of $166-171 \mathrm{~m} \mu \mathrm{s}^{-1}$ for glacier ice and $171-175 \mathrm{~m} \mu \mathrm{s}^{-1}$ for ice shelves. The distribution of the velocities in Antarctica is shown in Figure 1. The chart was calculated based on the sources mentioned above. Comparable values have been calculated from the electromagnetic properties of ice (Khokhlov, 1970; Luchininov and Macheret, 1971; Luchininov, 1977; Bogorodsky and others, 1983). These sources give $\varepsilon \approx 3.17\left(v=168.5 \mathrm{~m} \mu \mathrm{s}^{-1}\right)$. According to Figure 1 we expected the velocity of electromagnetic waves in ice near Vostok station to be about $168 \mathrm{~m} \mu \mathrm{s}^{-1}(\varepsilon=3.174)$.

\section{EQUIPMENT}

The wide-angle reflection measurements were made with a system consisting of the $60 \mathrm{MHz}$ ice radar RLS-60-98, a digital processing interface (DPI) and a satellite navigation system (Masolov and others, 1999; Lukin and others, 2000; Popov and others, 2000, 2001). The DPI is based on the industrial computer "Favorite-IPC" with a SBC-8259 processor (Axiom Technology Co). The analog-digital transformation used a 12-bit analog-digital converter AD9042AST (Analog Devices Inc.). The digitizing of the radar output data and its stacking were carried out in real time. The ice radar system specifications are given below:

$\begin{array}{ll}\text { mean frequency } & 60 \mathrm{MHz} \\ \text { pulse repetition frequency } & 600 \mathrm{~Hz} \\ \text { pulse length } & 0.5 \mu \mathrm{s} \\ \text { peak pulse power } & 60 \mathrm{~kW} \\ \text { bandwidth of the reception channel } & 3 \mathrm{MHz} \\ \text { time-step of digitization of the RES signal } & 0.05 \mu \mathrm{s} \\ \text { amplitude step of digitization of the RES signal } & 0.24 \mathrm{mV} \\ \text { stacking (integration) rate } & 256 \mathrm{sum} \\ \text { registration interval } & 1 \mathrm{~s}\end{array}$

The very widely spaced receiver and transmitter required a special system to trigger the receiver. We used a sound system whereby the leading edge of a sound pulse provided the trigger.

\section{RES TEGHNIQUE}

The wide-angle reflection soundings were made along two lines (northern with an azimuth $335^{\circ}$ and western with an azimuth $245^{\circ}$ ), each of them divided into 18 segments of $200 \mathrm{~m}$ (Fig. 2). The lines were laid out with a theodolite, with a maximal deviation of $\pm 0.05^{\circ}$ from a straight line. Marking was done with a $100 \mathrm{~m}$ metal tape with a margin of error of $\pm 0.1 \mathrm{~m}$. The transmitting antenna was fixed near a snowbound metal beam (point 0, Fig. 2). The receiving antenna was fixed on the roof of a mobile beam and, during the moving, was positioned strictly above marks at $3 \mathrm{~m}$ height from the ice surface. The velocity was calculated with a one-layer model which assumed a horizontal subsurface interface. The correctness of the applied model was confirmed by the natural measurements. It was provided with a RES survey 


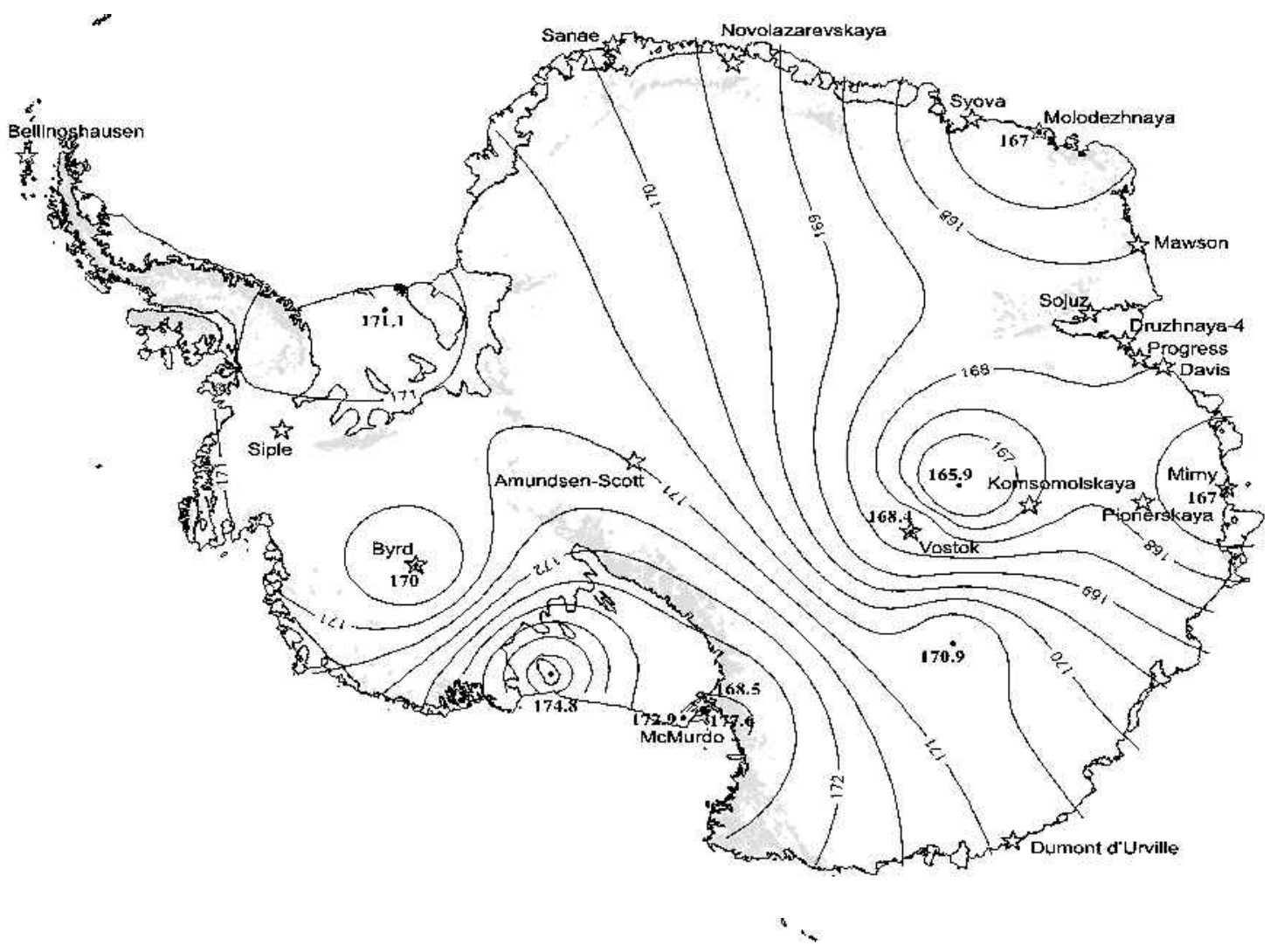

Fig. 1. Velocity of electromagnetic wave propagation in Antarctic ice sheet. Black points show measured data.

around Vostok station and mapping of the ice base of the area (Popov and others, 2001). One of the RES records is shown in Figure 3.

It is necessary to note that it would have been more correct to use the common depth point (CDP) technique, i.e. both antennas move equally from a center point (Bogorodsky and others, 1983). Unfortunately, this was technically impossible. The CDP technique is necessary when dealing with an inclined ice base, because then the point of reflection is fixed. In our case we dealt with horizontal layers, for which the points of reflections are fixed because of the extremely simple geometry of radio-wave propagation.

\section{PROGESSING OF THE DATA AND RESULTS}

The average velocity of radio-wave propagation in ice was calculated following Bogorodsky and others (1985). The mathematics of the geometry of radio-wave propagation are given as $b^{2}+(2 T)^{2}=L^{2}$, where $b$ is the distance between the antennas, $T$ is the ice thickness and $L$ is the radio ray distance in ice, for horizontal layers. $L=v \tau$, where $v$ is the average velocity of the radio-wave propagation in ice and $\tau$ is the delay of the reflected signal. By simple substitution

$$
\tau^{2}=\frac{b^{2}}{v^{2}}+4 \frac{T^{2}}{v^{2}}
$$

and we fit a straight line by the least-squares regression method (LSM). The regression coefficients are given as:

$$
v=\frac{1}{\sqrt{a_{1}}}, \quad \text { and } \quad T=\frac{1}{2} \sqrt{\frac{a_{0}}{a_{1}}},
$$

where $a_{1}$ and $a_{0}$ are the coefficients at the first and free members accordingly. Equation (1) and the coefficients (2) were calculated for each line (Fig. 4).
The average velocity of the radio-wave propagation in ice is found to be $168.36 \mathrm{~m} \mu \mathrm{s}^{-1}$ for the northern line and $168.43 \mathrm{~m} \mathrm{\mu s}^{-1}$ for the western line. Therefore, the average englacial velocity in the lake Vostok area is $168.4 \pm 0.5 \mathrm{~m} \mu \mathrm{s}^{-1}$. An account for the air layer only changes the second decimal and is not important.

\section{HYPERBOLIC DIFFRAGTION PROGESSING}

It is also possible to determine the average velocity of electro-

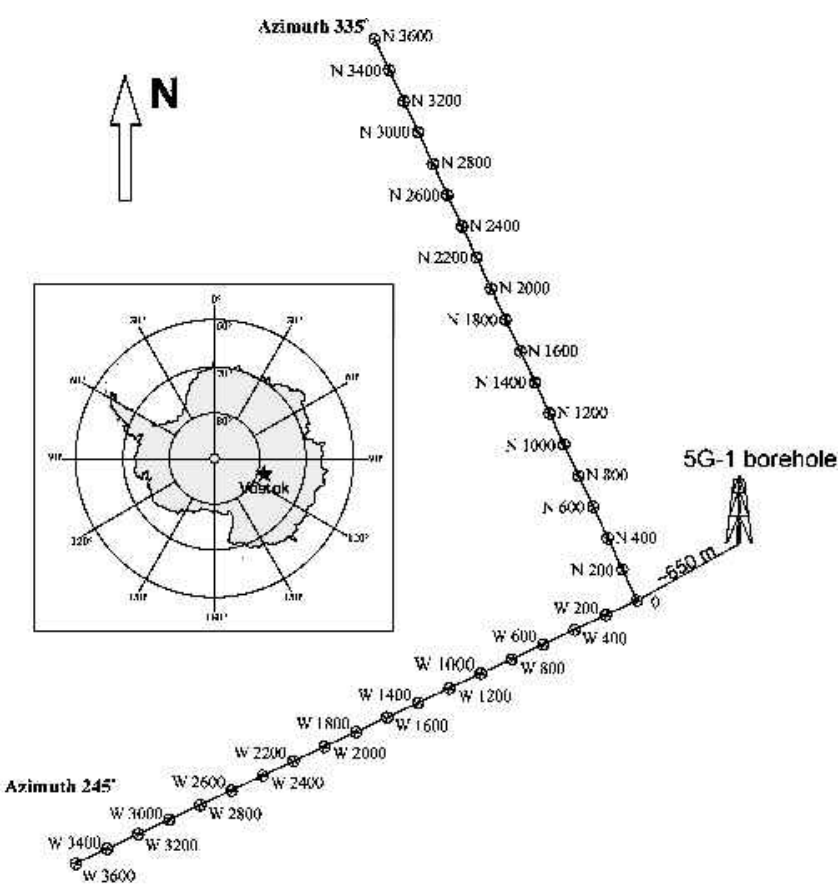

Fig. 2. Wide-angle reflection technique location chart. 


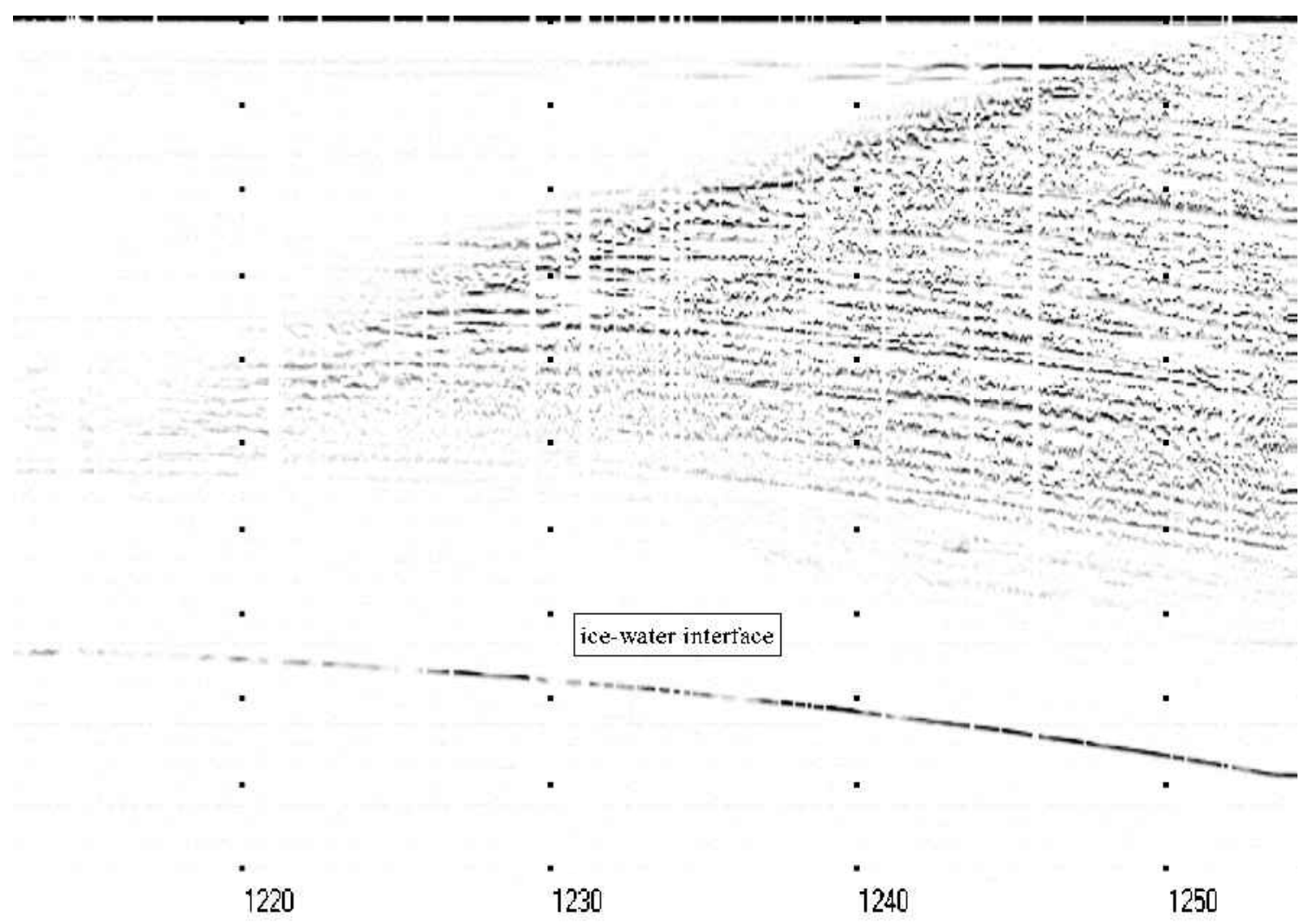

Fig. 3. RES record (western leg).

magnetic wave propagation using the hyperbolic diffractions (Macheret, 2000; Vasilenko and others, 2001). Radio-wave rays from a point diffractor are shown in Figure 5. If $x_{0}$ is the value of the abscissa at the apex of the hyperbola, $\xi_{i}$ is the distance between $x_{0}$ and $x_{i}, T$ is the ice thickness, $d$ is the lateral distance between the reflector and the RES route, and $\tau_{0}$ and $\tau_{i}$ are delays of the reflected signal (they correspond to distances $L_{0}$ and $\left.L_{i}\right)$, then, for the ray at $x_{0}$

$$
L_{0}^{2}=T^{2}+d^{2}=\frac{1}{4} v^{2} \tau_{0}^{2},
$$

and at $x_{i}$ we have

$$
L_{i}^{2}=T^{2}+\zeta_{i}^{2}=T^{2}+d^{2}+\xi_{i}^{2}=L_{0}^{2}+\xi_{i}^{2},
$$

where

$$
\tau_{i}^{2}\left(\xi_{i}^{2}\right)=\tau_{0}^{2}+4 \frac{\xi_{i}^{2}}{v^{2}}
$$

We can calculate a linear fit using regression coefficients calculated by LSM (Equation (3)). The velocity $v$ can be found through Equation (2), as described in Macheret (2000) and Vasilenko and others (2001).

We estimate our error, $\delta v$, is

$$
\delta v=v \sqrt{\left(\frac{\delta \tau_{0}}{\tau_{0}}\right)^{2}+\left(\frac{\delta \xi_{i}}{\xi_{i}}\right)^{2}+\left(\frac{\delta \tau_{i}}{\tau_{i}}\right)^{2}} .
$$

Z-record modeling (Fig. 6a) gives the relative height value $\delta v$. The errors $\delta \tau_{0}$ and $\delta \tau_{i}$ can be estimated as approximately $0.25 \mu \mathrm{s}\left(\tau_{0} \approx 45 \mu \mathrm{s}\right)$. We estimate the error $\delta \xi_{i}\left(\xi_{i} \approx\right.$ $2000 \mathrm{~m}$ ) as approximately $30 \mathrm{~m}$. Then, according to Equa-

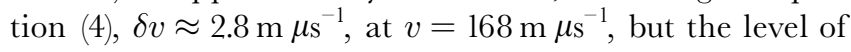
accuracy is unacceptable.

We can reduce the error (Popov, 2002) by considering the RES record amplitude $A=A(\tau)$. The digitizing was done on the leading edges (LES), i.e. on the maximum of the first derivative $\tau^{\prime}=\mathrm{d} A / \mathrm{d} \tau$. With the understanding that the LES of the reflections must be positive, we redefine $\tau^{\prime}$ as $\tau_{+}^{\prime}$ such that

$$
\tau_{+}^{\prime}=\left\{\begin{array}{ll}
\tau^{\prime}, & \text { if } \quad \tau^{\prime}>0 \\
0^{\prime}, & \text { if } \quad \tau^{\prime} \leq 0
\end{array} .\right.
$$

We then created a synthetic binary $\mathrm{Z}$ record that consists of two different values: black points (corresponding to peaks $\tau_{+}^{\prime}$ ) and white points (Fig. 6b). For obvious reasons, there will be a significant number of such peaks. We establish a limit $\varsigma$, which allows us to plot only peaks with $\tau_{+}^{\prime}>\varsigma$. Therefore, we can reduce the number of the peaks by varying $\varsigma$, which allows us to process the data more precisely (Fig. 6c).

We now estimate $\delta v$ again (Equation (4)). The $\delta \xi_{i}$ can be estimated as 1 point $(\approx 1.5 \mathrm{~m})$. Practically the same value is obtained for the carrier position determination. Hence, it is possible to accept $\delta \xi_{i} \approx 3 \mathrm{~m}$. The error in determining the position of the hyperbola apex can be estimated as 1 point ( $\approx 0.05 \mu \mathrm{s}$ ). According to Figure $6 \mathrm{c}$, the $\delta \tau_{i}$ could be estimated as $0.1 \mu$ s. Finally, $\delta v$ could be as little as $0.75 \mathrm{~m}^{-1} \mathrm{~s}^{-1}(\leq 0.5 \%)$.

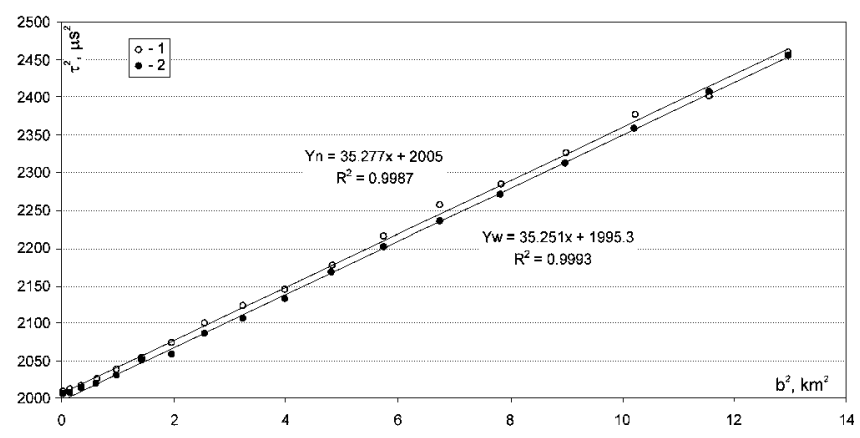

Fig. 4. Plots of the squares of the reflected signal delays vs squares of the distance between antennas, trend lines and best-fit equations. 1. The northern leg; 2. the western leg. 
There were three hyperbolic reflections in the RES data. The velocities were $168.46,168.52$ and $168.46 \mathrm{~m}_{\mathrm{s}}^{-1}$. The average value is $168.5 \mathrm{~m} \mathrm{~s}^{-1}$. This is close to the value defined by the wide-angle reflection technique, so velocity determination by hyperbolic diffractions could be used in future RES investigations.

\section{COMPARISON OF RESULTS WITH OTHER GEOPHYSIGAL MEASUREMENTS}

In addition to our work, vertical seismic profiling (VSP), thermometry, ice density determination and other geophysical investigations were carried out in borehole $5 \mathrm{G}-1$ and its vicinity. We estimate ice thickness from the convergence of all available data on the ice thickness. Based on RES data, the ice thickness in the vicinity of $5 \mathrm{G}-1$ borehole is $3775 \pm 15 \mathrm{~m}$. Based on VSP data, the ice thickness is $3760 \pm 30 \mathrm{~m}$ (Popkov and others, 1999). The thermometry data give a value of $3776 \pm 3 \mathrm{~m}$ (Salamatin and others, 1998). The divergence between all the data is $<1 \%$, which is quite good for so many methods.

\section{DISGUSSION: FIRN GORRECTION}

The precision of the velocity of electromagnetic wave propagation in ice by the wide-angle reflection method was

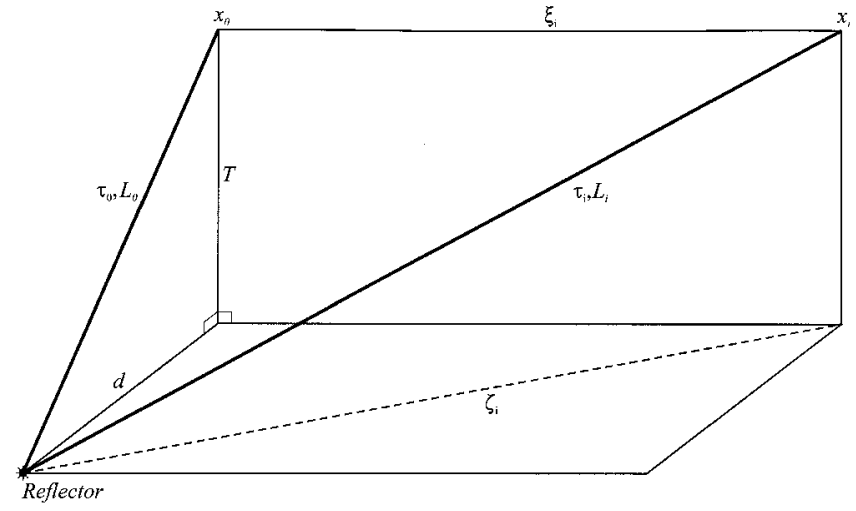

Fig. 5. Ray geometry of electromagnetic waves propagating from a point reflector.

discussed by Babenko and Macheret (1997). They used Rasmussen's approach by elliptic functions (Rasmussen, 1986) for the firn layer. Ice density, $\rho$, down the ice sheet was converted to refractive index $n$ with the following dependence: $n=1+K \rho$, where $K=(8.51 \pm 0.1) \times 10^{-4} \mathrm{~m}^{3} \mathrm{~kg}^{-1}$ (Babenko and Macheret, 1997). We believe that the approach of Rees and Donovan (1992) was more correct because they used $K=(8.4 \pm 0.1) \times 10^{-4} \mathrm{~m}^{3} \mathrm{~kg}^{-1}$ (Rees and Donovan, 1992), but for our estimation this difference is not important.

We estimated the firn correction for the vicinity of Vostok
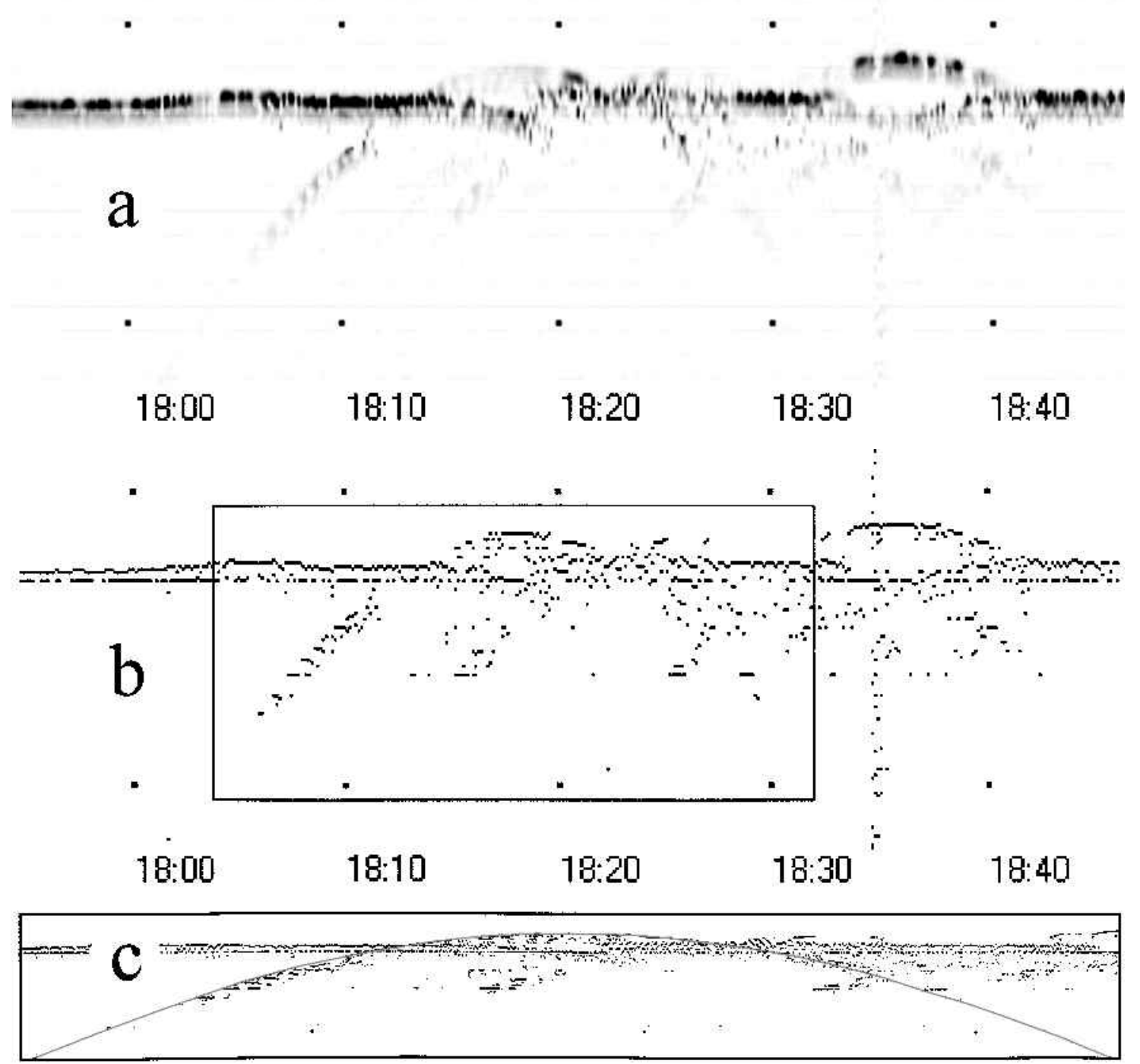

Fig. 6. Hyperbolic diffractions and their modeling; ( a) Zrecord; (b) RES record formed using the described method; (c) modeling. 
station following Babenko and Macheret (1997). For an ice thickness of $T \approx 4000 \mathrm{~m}$, firn thickness of $T_{\text {firn }}=105 \mathrm{~m}$ (Salamatin and others, 1985) and surface snow density of $\rho_{0}=320 \mathrm{~kg} \mathrm{~m}^{-3}$ (Ekaykin and others, 1998), the error of the

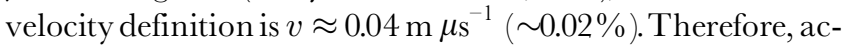
counting for the firn layer impact on the velocity of electromagnetic wave propagation in ice is not important for RES investigations.

\section{GONCLUSIONS}

We have measured the electromagnetic wave propagation velocity in the vicinity of Vostok station by the wide-angle reflection method. It is a relatively complex method that requires some special observations that are not easy to perform. Our knowledge of the velocity in Antarctica forces us to lower the accuracy of ice-thickness measurements to $3 \%$ mainly because of velocity scattering. We also tried to analyze the diffractions from discontinuities in the ice. As shown above, this method could be used for a ground-based RES survey and would allow measurements of electromagnetic wave propagation velocity in remote areas with an accuracy due to velocity scattering of $<0.5 \%$.

On the other hand, it is important to define the velocity in remote parts of Antarctica (or the Arctic) for airborne RES. Perhaps this could be done based on an analysis of the diffraction from discontinuities, but for a more complex model. Solving this problem would lead to an increase in the accuracy of RES investigations.

\section{ACKNOWLEDGEMENTS}

The authors would like to express their sincere gratitude to M. Studinger, O. B. Soboleva, J. B. Guseva and N. D. Aleshkova for their assistance with the work. We also thank the referees J.W. Glen and S. A. Arcone for their helpful comments and suggestions.

\section{REFERENGES}

Babenko, A. N. and Yu. Ya. Macheret. 1997. Vliyanie sloya firna na tochnost' izmereniya parametrov polyarnyh lednikov metodom naklonnogo radiozondirovaniya [Firn layer effect upon measurement accuracy of the polar glaciers parameters by radio echo sounding]. Mater. Glyatsiol. Issled./Data Glaciol. Stud. 83, 185-190.

Bogorodsky, V.V., C. R. Bentley and P. E. Gudmandsen. 1985. Radioglaciology. Dordrecht, etc., D. Reidel Publishing Co.

Clough, J.W. and C. R. Bentley. 1970. Measurements of electromagnetic wave velocity in the East Antarctic ice sheet. International Association of Scientific Hydrology Publication 86 (Symposium at Hanover 1968 - Antarctic Glaciological Exploration ( ISAGE) ), 115-128.

Drewry, D. J. 1975. Comparison of electromagnetic and seismic-gravity ice thickness measurements in East Antarctica. 7. Glaciol., 15(73), 137-150.

Ekaykin, A. A., V. Ya. Lipenkov and N. I. Barkov. 1998. Prostranstvennovremennaya struktura poly snegonakopleniya v rayone stantsii Vostok, Tsentral'naya Antarktida [Temporal-spatial structure of snow accumulation field in the vicinity of Vostok station, central Antarctica]. Vestnik St. Peterb. Univ, Ser. 7, 4(28), 38-50.

Jiracek, G. R. and C. R. Bentley. 1971. Velocity of electromagnetic waves in Antarctic ice. In Crary, A. P., ed. Antarctic snow andice studies II. Washington, DC, American Geophysical Union, 199-208. (Antarctic Research Series 16.)

Khokhlov, G. P. 1970. Issledovanie elektricheskikh kharakteristik presnogo l'da na razlichnykh modelyakh ego tekstur [Studying electrical properties of fresh-water ice in various models of its structure]. Arkt. Antarkt. NauchnoIssled. Inst. Trudy 295, 22-27.

Luchininov, V.S. 1977. Radiolokatsionnoe zondirovanie i ego primenenie v glyatsiologii [Radio echo sounding and its application in glaciology] In Losev, K. S., ed. Geofizicheskiye metody v glyatsiologii [Geophysical methods in glaciology]. Moscow, Vsesoyuznyy Institut Nauchnoy i Tekhnicheskoy Informatsii (VINITI). Itogi Nauki i Tekhniki, 87-192. (Glyatsiologiya 1.)

Luchininov, V. S. and Yu. Ya. Macheret. 1971. Elektromagnitnoe zondirovanie teplyh gornyh lednikov [Electromagnetic sounding of warm mountain glaciers]. Zh. Tekh. Fiz., 41(6), 1299-1309.

Lukin, V. V., V. N. Masolov, A.V. Mironov, A. M. Popkov, S.V. Popov and A. N. Sheremet'yev. 2000. Rezul'taty geofizicheskih issledovaniy podlednikovogo ozera Vostok (Antarktida) v 1995-1999 gg [Results of geophysical researches of subice Lake Vostok (Antarctica) in 1995-1999]. Probl. Arkt. Antarkt. 72, 237-248.

Macheret, Yu.Ya. 2000. Otsenka soderzhaniya vody v lednikakh po giperbolischeskim otrazheniyam [Estimation of water content in glaciers from hyperbolic reflections]. Mater. Glyatsiol. Issled./Data Glaciol. Stud. 89, 3-10.

Masolov, V. N. and 7 others. 1999. Earth science studies in the Lake Vostok region: existing data and proposals for future research. In International Workshop on Subglacial Lake Exploration, September 1999, Cambridge, England.Workshop report. Cambridge, Scientific Committee on Antarctic Research, 1-18.

Popkov, A. M., S. R. Verkulich, V. N. Masolov and V.V. Lukin. 1999. Seysmicheskiy razrez v rayone stantsii Vostok (Antarktida): rezul'taty issledovaniy 1997 goda [Seismic section at Vostok station vicinity (Antarctica): result of studies in 1997]. Mater. Glyatsiol. Issled./Data Glaciol. Stud. 86, 152159

Popov, S.V. 2002. Opredelenie sredney skorosti rasprostraneniya elektromagnitnyh voln v lednike po giperbolicheskim otrazheniyam ot neodnorodnostey [Assessment of average velocity of electromagnetic wave propagation in glacier by hyperbolic reflections from discontinuities.]. Mater. Glyatsiol. Issled./Data Glaciol. Stud. 92, 223-225.

Popov, S. V., A. V. Mironov and A. N. Sheremet'yev. 2000. Rezul'taty nazemnyh radiolokatsionnyh issledovaniy podlednikovogo ozera "Vostok" v 1998-2000 gg [Result of ground RES researches of subice Lake Vostok in 1998-2000] Mater. Glyatsiol. Issled./Data Glaciol. Stud. 89, 129-133.

Popov, S.V., A.V. Mironov, A. N. Sheremet'yev and V. S. Luchininov. 2001. Izmerenie sredney skorosti rasprostraneniya elektromagnitnyh voln v lednike v rayone stantsii Vostok [Measurements of average velocity of electromagnetic wave propagation in Vostok station area]. Mater. Glyatsiol. Issled./Data Glaciol. Stud. 90, 206-208

Rasmussen, L. A. 1986. Refraction correction for radio echo-sounding of ice overlain by firn. f. Glaciol., 32(111), 192-194.

Rees, W. G. and R. E. Donovan. 1992. Refraction correction for radio-echo sounding of large ice masses. F. Glaciol., 38(129), 302-308.

Robin, G. de Q., S. Evans andJ.T. Bailey. 1969. Interpretation of radio echo sounding in polar ice sheets. Philos. Trans. R. Soc. London, Ser. A, 265(1166), 437-505.

Salamatin, A. N., V. Ya. Lipenkov, K. Ye. Smirnov and Yu. V. Zhilova. 1985. Plotnost' lednikovogo l'da i yego reologicheskiye svoystva [Density and rheological properties of glacier ice]. Antarktika 24, 94-106.

Salamatin, A. N., R. N. Vostretsov, J.-R. Petit, V. Ya. Lipenkov and N. I. Barkov. 1998. Geophysical and palaeoclimatic implications of the stacked temperature profile from the deep borehole at Vostok station, Antarctica. Mater. Glyatsiol. Issled./Data Glaciol. Stud. 85, 233-240.

Sheremet'yev, A.N. 1989. Izmerenie skorosti rasprostraneniya elektromagnitnyh volnv lednike na Kupole "V" vAntarktide [Measurement of electromagnetic wave velocity in Cape B, Antarctica]. In Bogorodskiy, V.V., ed. Elektrofizicheskiye i fiziko-mekhanicheskiye svoystva l'da Electrophysical and physical-mechanical properties of ice ]. Leningrad, Gidrometeoizdat, 59-64.

Trepov, G.V. 1970. Izmerenie skorosti rasprostraneniya elektromagnitnyh voln $\mathrm{v}$ lednike [Measuring the velocity of electromagnetic wave propagation in a glacier]. Arkt. Antarkt. Nauchno-Issled. Inst. Trudy 295, 60-63.

Van Autenboer, T. and H. Decleir. 1972. Ice thickness and subglacial relief of the Jelbartisen-Trolltunga area, Dronning Maud Land. In Adie, R. J., ed. Antarctic geology and geophysics. Oslo, Universitetsforlaget, 713-722. (International Union of Geological Sciences, Ser. B, No. 1.)

Vasilenko, Ye.V. and 7 others. 2001. Radiophizicheskie issledovaniya lednika Aldegonda na Shpitsbergene v 1999 g [Radiophysical researches of Aldegondabreen, Spitsbergen in 1999]. Mater. Glyatsiol. Issled./Data Glaciol. Stud. 90, 86-99. 